\title{
PAN系T-300炭素繊維の空気酸化速度と光の機構
}

\author{
野村真三*·斉藤 保*·今井 久*
}

(平成元年 7 月 20 日受理)

\section{Kinetic Mechanism for Air Oxidation of PAN T-300 Carbon Fiber}

Shinzo Nomura, Tamotsu Saito and Hisashi Imai

Japan Atomic Energy Research Institute, Tokai-mura, Ibaraki-ken 319-11, Japan

Kinetic mechanism of air oxidation was studied for PAN T-300 carbon fiber in a temperature range from 500 to $600^{\circ} \mathrm{C}$. Rates of the oxidation for the fiber can be described as the following auto-catalytic rate equation:

$$
\mathrm{d} \alpha / \mathrm{dt}=\mathrm{k} \alpha(1-\alpha)
$$

Arrehenius plot of the rate constant, $k$, gave single straight line and the activation energy for the oxidation was estimated to be $-22.7 \mathrm{kcal} / \mathrm{mol}$. The energy was a half of that reported for Celion 6000 graphitized carbon fiber. A homogeneous shrinkage oxidation mechanism did not meet either with the oxidation rate behavior or the fiber radius change with burn-off. SEM observation and laser Raman spectroscopy for the oxidized fibers also supported the auto-cataly tic oxidation mechanism.

KEYWORDS: Carbon fiber, Air oxidation, Raman spactra, Auto-catalytic mechanism

\section{1.はじめに}

炭素織維を補強材とする炭素複合材料抢よびプラスチ ック複合材料は軽量高強度の構造素材として注目を集め

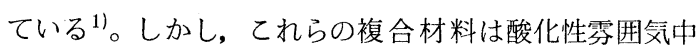
では酸化されやすく，ての点が使用上の制約条件となっ ている。複合材料の耐酸化性を向上させるためには, 各 要素の耐酸化性を向上させるほか, 酸化の合成則を知る 必要がある。合成則の構成因子には：(1)炭素繊維, マト リックス材料それぞれの酸化速度, (2)界面の導入による 酸化の相乗効果, (3)複合材料の酸化の異方性之炭素繊維 の配列方向との関係, などが考えられるが, てれら個々 の因子について詳しく検討した報告は少ない2)-4)。われ われは以上の構成要素のうち, (1)の繊維材の酸化反応の

*日本原子力研究所東海研究所燃料 - 材料工学部 :

于319-11 茨城県那坷郡東海村白方白根 2 の 4
機構について検討した。

炭素繊維表面のガス吸着特性については, Ismail が PAN系T-300繊維を测定している5)。それによると, BET 表面積は繊維の幾何学的表面積の 1.5 倍にすぎず, 細孔の開気孔率は小さい。しかし, BET 表面積中に占 める活性表面積の割合は14\%と大きい。

酸化にともなう炭素繊維内の黒鉛微結晶組織の変化は レーザーラマン分光によって検討するととができる。 $1360 \mathrm{~cm}^{-1}$ および $1580 \mathrm{~cm}^{-1}$ バンドの強度比 $\mathrm{I}_{1360} / \mathrm{I}_{1580}$ は, 炭素繊維の微結晶組織の同定に有効であると認めら れている(6)-8)。本報告では, 炭素繊維(PAN系T-300) の空気酸化に打ける速度論的解析のほか, SEM (走査型 電子顕微鏡）による表面観察およびラマンスペクトルの 測定結果について述べた。 


\section{2. 実験}

\section{1 試 料}

沛販のPAN 系T-300炭素繊維(東レ製)を長さ $20 \mathrm{~mm}$ に切り, トリクロールエチレン浴中で 3 回超音波洗浄を 行なった後, $110^{\circ} \mathrm{C}$ で 3 時間空気浴中で乾燥して空気酸 化用試料とした。表面観察抢よびラマン分光用試料とし ては, 超音波洗浄した T-300 (A. R. (As recieved)) 繊 維掞よび $525^{\circ} \mathrm{C}$ で空気酸化した $\mathrm{T}-300$ 瀻維を用いた。

\section{2 空気酸化}

約 $0.15 \mathrm{~g}$ の試料を $4 \mathrm{~cm} \phi \times 4 \mathrm{~cm}$ の磁性ルッボに分散 して入れ, 上下面加熱型の卓上マッフル炉中, 自然対流 条件下で空気酸化を行なった。反応温度範囲は500 600 ${ }^{\circ} \mathrm{C}$ とした。炉内温度の变動幅は土 $3^{\circ} \mathrm{C}$ であった。所定 温度で酸化した後, シリカゲル入りデシケーター中で一 時間放冷し, 直ちに重量測定を行った。1つの試料を所 定の時間間隔で酸化し, その都度重量測定を行うという 万法で酸化率一時間曲線を定めた。重量測定には秤量感 度 $0.01 \mathrm{mg}$ の電子天秤を用いた。

\section{3 表面観察とラマン分光}

表面観察には日本電子製の JSM-840A 型SEMを用い， 加速電圧 $7 \mathrm{KV}$ 以下で行った。観察試料仙は金蒸着は行 っていない。SEM 写真から各酸化率でとの平均繊維直 径を定め, 酸化率一平均半径曲線を作成した。

ラマンスペクトルは日本分光工業製の NR-1100 型レー ザーラマン分光器を用いて測定した。波長514.5nmのアルゴ ンーイオンレーザー光を用い, 対物レンズ100倍抢よび 50倍としてマイクロラマン測定を行った。レーザービー ムスポットの直径は $1 \mu \mathrm{m}$ または $2 \mu \mathrm{m}$ である。光電子 倍増管の泠却は行っていない。レーザービームによる T300 繊維の損傷をさけるため, レーザー出力は $10 \sim 50$ $\mathrm{mW}$ の範囲とした。T-300 瀻維の酸化率が大きくなる にしたがい,レーザービームの出力を小さくした。

\section{3. 結 果}

\section{1 酸化反応の動力学的解析}

酸化率 $(\mathrm{B} ・ \mathrm{O})$ の反応時間による変化は $\mathrm{S}$ 字曲線を示 した（Fig. 1)。乙の曲線を以下の 2 つのモデルで解析 した。

\subsection{1 均一肉減りモデル}

細孔の開気孔率が小さく, しかむ反応表面に占める微 結晶子のエッジ面の割合が大きい T-300 (A.R.) 緘維で は, 酸化が緘維表面から均一に肉減りで進行すると仮定 するのが自然である。乙の場合には, 酸化反応速度が炭 素繊維の幾何学的表面積に比例するから, 次式が成り立 D。

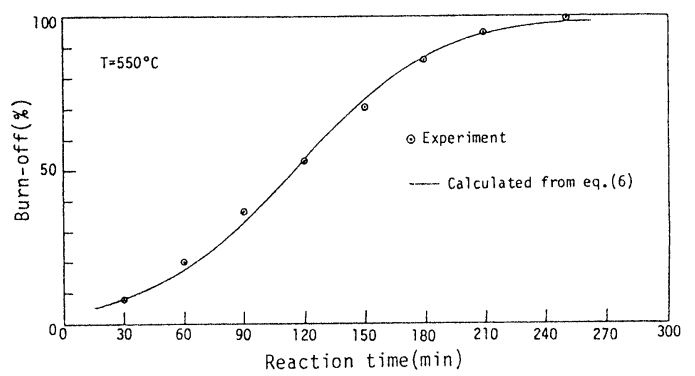

Fig. 1 Change of burn-off with reaction time at $550^{\circ} \mathrm{C}$ for as-recieved PAN T-300 carbon fiber.

$$
\mathrm{d} \alpha / \mathrm{dt}=\mathrm{k} \times 2 \pi \mathrm{r}
$$

こてで, $\alpha$ は反応率, $\mathrm{k}$ は速度定数, $\mathrm{r}$ は反応時間 $\mathrm{t}$ に 打ける炭素繊維の半径を表わす。酸化量が肉減りによっ て決定される場合には, 炭素繊維内部の密度は一定に保 たれるから，次式が成り立つ。

$$
\alpha=1-\left(\mathrm{r} / \mathrm{r}_{0}\right)^{2}
$$

$r_{0}$ は反応前の炭素繊維の半径である。(1), (2)式より， $\alpha$ と $\mathrm{t}$ との間に次式が成り立つ。

$$
1-\sqrt{1-\alpha}=\mathrm{k} \pi \mathrm{r}_{0}^{2} \mathrm{t}
$$

反応温度 $550^{\circ} \mathrm{C}$ に打けるデータを(3)式で整理した結果を Fig. 2 亿示した。実測值は酸化率20\%以下でこのモデル

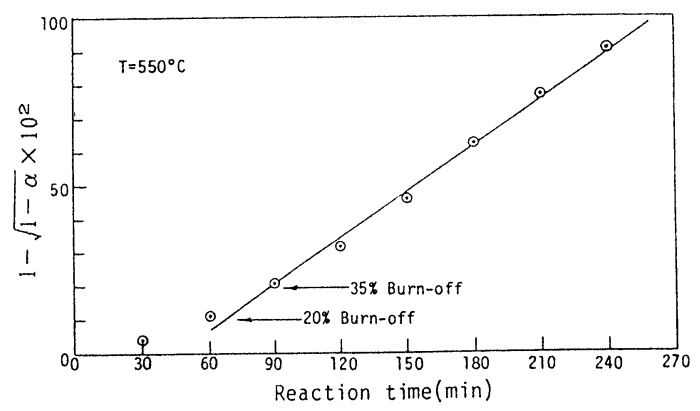

Fig. 2 Relation between burn-off at $550^{\circ} \mathrm{C}$ and reaction time of as-recived PAN T-300 carbon fiber.: Homogeneous shrinkage oxidation model.

から外れる傾向を示す。直線の外挿と横軸との交点は 45 min である。試料を炉内で $30 \mathrm{~min}$ 間酸化するでとに炉 外に取り出して酸化率を定めている。したがって, 上記 の $45 \mathrm{~min}$ は反応の誘導期間としては大きすぎる。肉減 りモデルに乗るためには $45 \mathrm{~min}$ の遅れ時間が必要であ るという結果は, このモデルが実測值と一致しないとと 
を示している。

炭素瀻維の酸化率と平均半径との関係をFig. 3 亿示し た。乙の図では, 反応時間の因子を除去できるので, 炭 素繊維の酸化が肉減りのみによって生じているか否かを 誘導期間の有無とは無関係に検証するてとができる。図

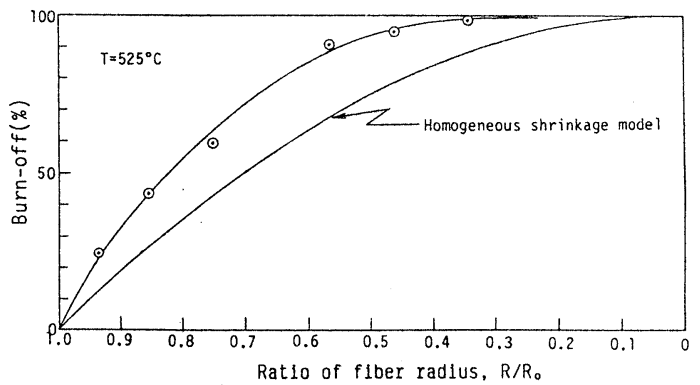

Fig. 3 Change in the fiber radius with burn-off at $525^{\circ} \mathrm{C}$.

中の丸印は実測値を示し, Homogeneous shrinkage model として指示されている曲線は(2)式による計算値 を示している。実測值は(2)式と一致しない。同一酸化率 で見た肉減りの実測值は, 測值は, (2)式による計算値よ りあ小さく, しかも，そのずれ巾は酸化率が増加するに つれて大きくなる。このととは, 酸化反応が炭素繊維の 内部まで浸透しているてとを示している。McKeeらは PAN ベースのModmor I 炭素䋐維を空気中, $700^{\circ} \mathrm{C}$ で 酸化率 $68 \%$ まで酸化したとてろ, 炭素繊維の直径が $8 \mu \mathrm{m}$ から $6 \mu \mathrm{m}$ 亿減少したと報告している ${ }^{9)}$ 。乙の值は Fig, 3 亿示した実測值と良く一致している。

\section{1 .2 自触媒型反応モデル}

PAN系T-300 (A.R.) 纎維は層間距離 $0.344 \mathrm{~nm}$ で, 結晶子の大きさ $\mathrm{L}_{\mathrm{a}}=3.5, \mathrm{~L}_{\mathrm{c}}=2.9 \mathrm{~nm}$ の乱層構造の微 結晶子から構成されていると考えられる100。さらに， skin-core 構造は示さない11)。そこで炭素䋐維を微視的 には個々のバラバラな微結晶子の集合体とみなし, 微結 晶子のそれぞれは直接, 空気中の酸素分子と接触できる 環境汇あると仮定する。乙の仮定は T-300(A.R)繊維 内の細孔の開気孔率が小さい事実と一見矛盾するように 見える。しかし, ある程度の酸化が進み, 閉気孔の開孔 が期待できるようになれば, 乙の条件が実現する可能性 がある。このモデルでは, 炭素䋐維の酸化反応速度は未 反応部分の量に依存するから次式が成り立つ。

$$
\mathrm{d} \alpha / \mathrm{dt} \propto(1-\alpha)^{\mathrm{m}}
$$

$\mathrm{m}$ はパラメータである。さらに, 実測された酸化反応速 度が $\alpha=0.5$ 付近で最大値を示すととから, $\mathrm{d} \alpha / \mathrm{dt}$ は $\alpha$ にも関係し， $\alpha$ 之 $(1-\alpha)$ との積の形にならなければ ならない。

$$
\mathrm{d} \alpha / \mathrm{dt}=\mathrm{k} \cdot \alpha^{\mathrm{n}}(1-\alpha)^{\mathrm{m}}
$$

こてで $\mathrm{k}$ は反応速度定数, $\mathrm{n}$ はパラメータである。ての 式は 1 つの微結晶子が反応するてとによって, 未反応部 分の微結晶子を一定の割合で活性化する，いわゆる自触 媒型の反応速度式である。簡単のために $\mathrm{n}=\mathrm{m}=1$ とお いて積分すると次式が得られる。

$$
\ln (\alpha / 1-\alpha)=\mathrm{k}\left(\mathrm{t}-\mathrm{t}_{0}\right)
$$

$\mathrm{t}_{0}$ は積分定数である。Fig. 1 亿示した $550^{\circ} \mathrm{C}$ に扔ける酸 化データを(6)式で整理し，Fig.4亿示した。丸印は実測

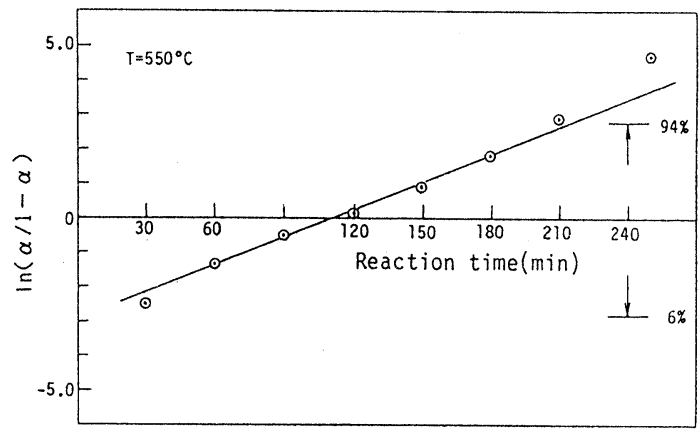

Fig. 4 Relation between burn-off at $550^{\circ} \mathrm{C}$ and reaction time of as-recieved PAN T-300 fiber.: Auto-catalytic type oxidation model.

值を，実線は(6)式による最小二乗線を示す。乙のモデル は酸化率が 6 \% から94\%の範囲内で実測值と良く一致し ている。前出の Fig.1 亿示した実線は, Fig.4 のプロッ 卜から定めた $\mathrm{k}, \mathrm{t}_{0}$ を用いて(6)式から得られた計算值で あり，実測値と良く一致している。Fig. 5 に, Fig. 1 と 同様に $550^{\circ} \mathrm{C}$ 以外の反応温度における酸化デー夕につい て, 実測値と計算值とを比較して示した。自触媒型のモ デルは $500 \sim 600{ }^{\circ} \mathrm{C}$ の温度範囲で実測値と良く一致する

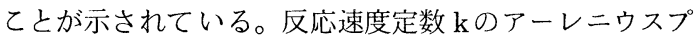
ロットをFig. 6 亿示した。アーレニウスプロットは一本 の直線になった。乙れは, $500 \sim 600^{\circ} \mathrm{C}$ の温度範囲で酸 化反応が同一の反応機構に支配されていることを示す。

Fig. 6 から定めた酸化反応の活性化エネルギーは, $\Delta \mathrm{H}$ $=-22.7 \mathrm{kcal} / \mathrm{mol}$ であった。乙の值は, Celion 6000 黒鉛 緘維について Bowlesら ${ }^{4)}$ が得た值, $\Delta \mathrm{H}=-39.9 \mathrm{kcal} /$ $\operatorname{mol}$ の納1/2である。

\section{2 SEM 観察}

A.R. および酸化率 $3,24,44,59,90,94,98 \%$ の300 䋐維について SEMによる表面観察を行った。T-300 （A.R.）繊維の表面には, 繊維軸に平行に数多くの条痕 が走っていた。しかし, 直径 $50 \mathrm{~nm}$ 以上のマクロポアー 

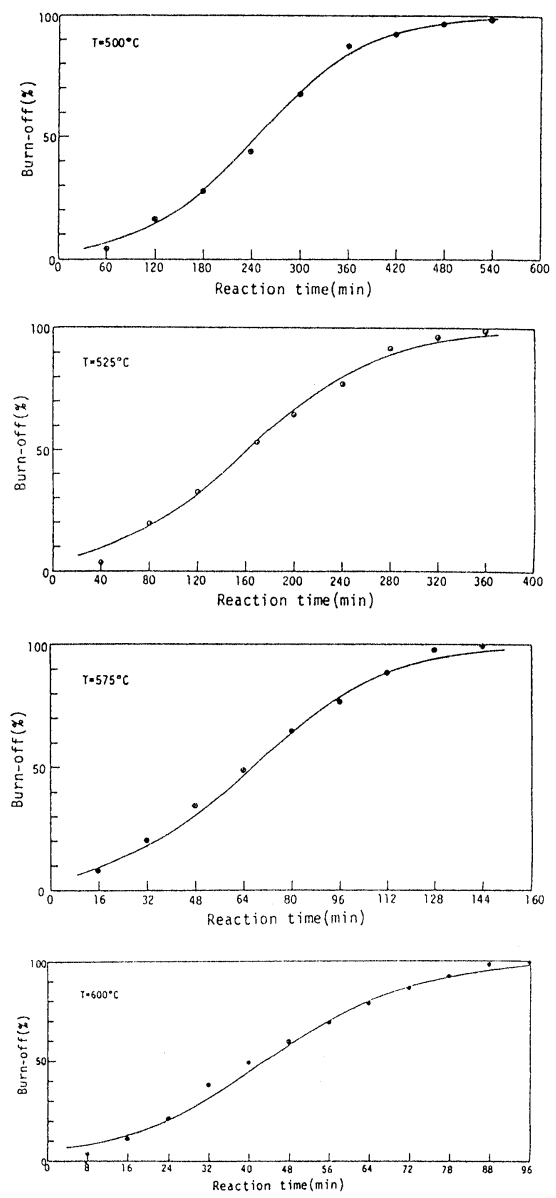

Fig. 5 Comparison of the oxidation rate behabior observed and value caluculated from eq. (6).

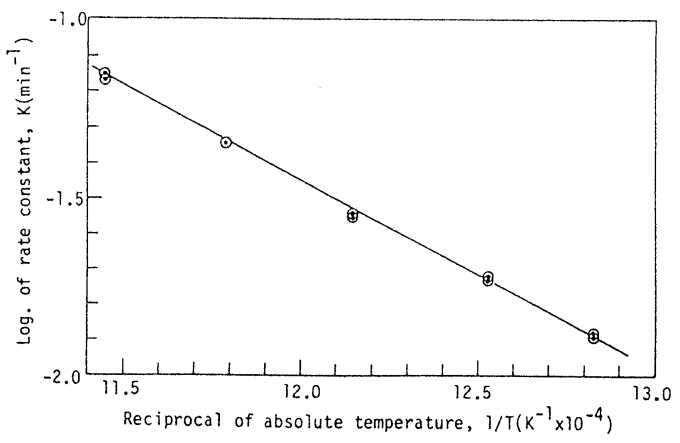

Fig. 6 Arrhenius plot for the rate constant of auto-catalytic oxidation mechanism.

の存在は認められなかった。さらに, 金属不純物の存在
を示す小笑起 ${ }^{12)}$ は,ほとんど認めなかった。Fig. 7 亿酸 化した T-300繊維の SEM 写真を示した。遠藤と小山は 市販の PAN 系炭素瀻維を空気中, $600^{\circ} \mathrm{C}$ で 1 時間酸化 したとてろ, 酸化ピットが生成したと報告している ${ }^{3)}$ 。 Harris らは ${ }^{13)}$ PAN 系Modmor I 炭素繊維について空 気中, $550^{\circ} \mathrm{C}$ で16時間の酸化でピットが生成したとして いる。McKee らは9 ${ }^{9)}$ ModmorI 炭素瀻維を空気中, 700 ${ }^{\circ} \mathrm{C}$ で酸化したとてろ, 酸化率 $8 \%$ で生成したピットが 酸化率30\%では消失したと報告している。さらに，炭素 繊維中に金属不純物が存在すると, 酸化速度を加速し ${ }^{14)}$, ピットを生成する ${ }^{15)}$ 乙とは良く知られている。しかし, われわれの実験では酸化のすべての段階で酸化ピットの 発生は認めら机かった。ての事実と,T-300(A.R.) 繊維の表面に小突起がほとんどなかったてとから，酸化 反応の機構が炭素瀻維中に介在する金属不純物による触 媒律速反応である可能性は排除できる。繊維に平行な条 痕の平滑化は, 酸化率59\%の繊維からはっきりと認めら れるようになった。酸化率が $94 \%$ になてあ条痕の存在 は認められたが, 同時に炭素䋐維の“焼きちぢれ”が始 まった。98\%の酸化を受けた炭素絾維は Fig.7 の B-4 に示されているように，全体的に“焼きちぢれ”を起し て抢り, 表面の条痕むほぼ消失していた。酸化の機構が 均一肉減りであるとした場合, その準備段階として一定 の酸化率まで酸化される必要があることを前に述べた。 酸化率 $3,24,44 \%$ の炭素繊維の表面を精査したが, 肉 減り酸化の起点となりうるような表面の肌荒れの発生は 認められなかった。乙のととと, 高酸化率まで条痕が残 っているととは, 肉減り酸化モデルにとって不利な状況 証拠である。

\section{3 レーザーラマン分光}

酸化率 $3,59 \%$ の $\mathrm{T}-300$ 繊維のラマンスペクトルを Fig. 8 亿示した。 $1600 \mathrm{~cm}^{-1}, 1350 \mathrm{~cm}^{-1}$ を中とする 強度の大きな 2 本のバンドが存在するほか, $2705 \mathrm{~cm}^{-1}$ にも非常にブロードなバンドの存在が認められた。1000 $1800 \mathrm{~cm}^{-1}$ 亿かけてのスペクトルの形状は無定形炭素の ラマンスペクトル16) 之は明らかに異って扔り,ガラス 状炭素やカーボンブラックのそれ(6),7) と良く似ている。 このととは, PAN系T-300 緘維が無定形炭素ではなく, メソフェーズ液晶の生成を経ない炭化過程で生成された 黒鉛微結晶子から構成されているてとを示している。乱 れた構造をむつ炭素では, $1600 \mathrm{~cm}^{-1}$ のピークがダブレ ットになるてとが知られている6), 8)。バックグラウンド を直線とし、ローレンツ型の強度分布を仮定 $\left.{ }^{81}, 17\right)$ して実 測スペクトルを分解した結果を Fig.8 亿示した。図中の 丸印は実測值を，点線は分解スペクトルを，実線はこれ らによる合成線を表わす。 $1600 \mathrm{~cm}^{-1}, 1350 \mathrm{~cm}^{-1}$ のバン 

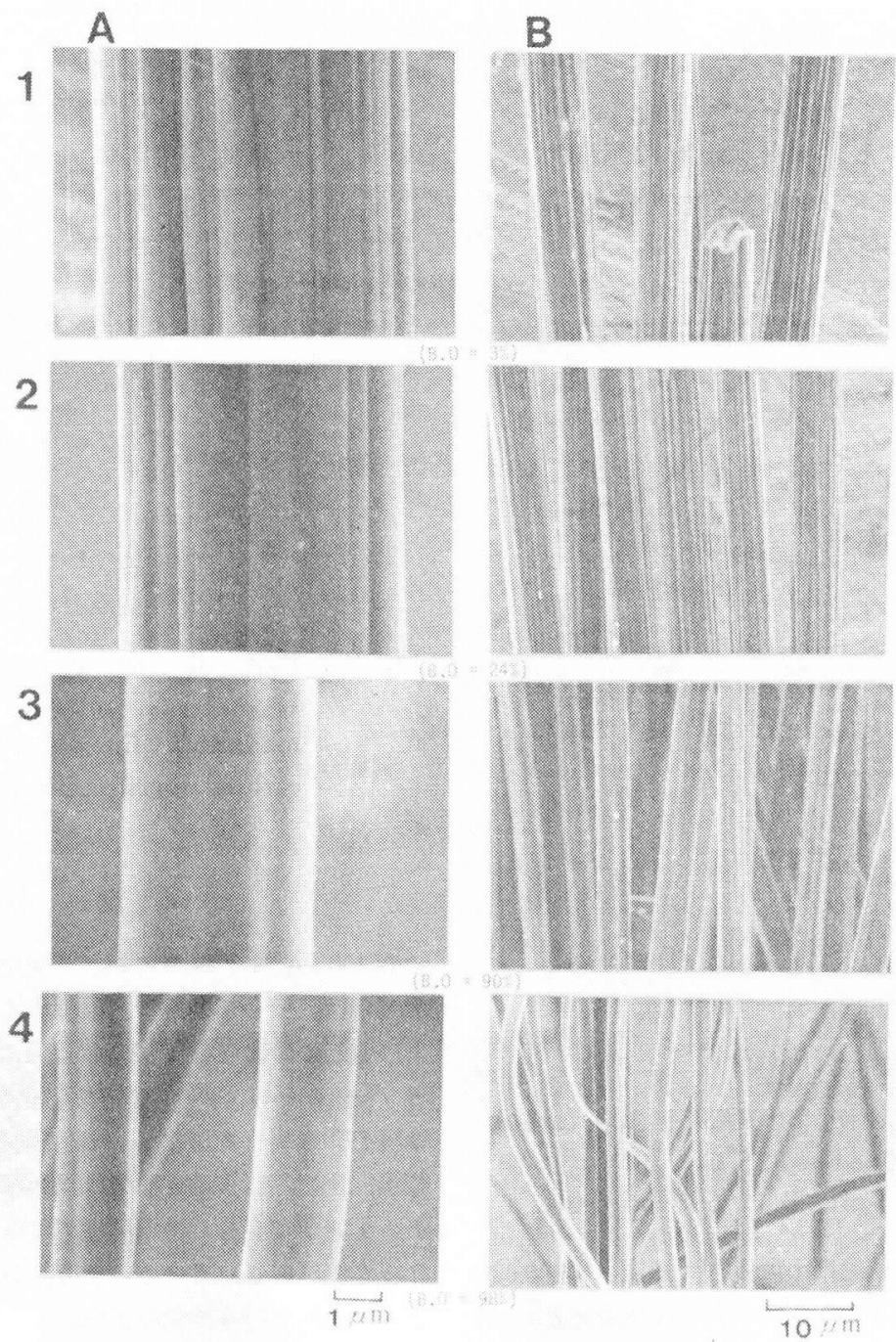

Fig. 7 SEM image of PAN T-300 carbon fibers oxidized at $525^{\circ} \mathrm{C}$.

ドは $1350 \mathrm{~cm}^{-1}(\mathrm{D}), 1560 \mathrm{~cm}^{-1}(\mathrm{G}), 1605 \mathrm{~cm}^{-1}\left(\mathrm{D}^{\prime}\right) の$ 3 本のピークから構成されていることが判る。こてで $\mathrm{G}$, D, D'の 3 本のピークは通常の $1360 \mathrm{~cm}^{-1}, 1580 \mathrm{~cm}^{-1}$,

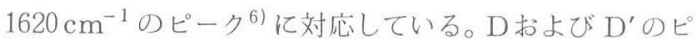
一クは乱れた黒鉛結晶に由来するラマン線であるとされ 6), 18), 19), 黒鉛綱平面内の単位格子移動の対称性の低下 によって黒鉛結晶のフォノン状態密度関数のピーク波数 $\left(\mathrm{D}, \mathrm{D}^{\prime}\right)$ が観測されるようになると説明されている ${ }^{18)}$ 。 Lespade 等は ${ }^{20)} 2$ 次元黒鉛綱平面結晶内のコヒーレン 卜な長さ ( $\left.\mathrm{L}_{\mathrm{a}}\right)$ が $10 \mathrm{~nm}$ から $2.5 \mathrm{~nm}$ まで減少するに つれて, 完全結晶から来る $1580 \mathrm{~cm}^{-1}$ の鋭いピークが 1600 $\mathrm{cm}^{-1}$ を中心とするブロードなピークに移行することを
示した。黒鉛結晶のフォノン状態密度関数には $1580 \mathrm{~cm}^{-1}$ (G)のピークは存在しない21)。したがって, 実測スペク トルに $1560 \mathrm{~cm}^{-1}(\mathrm{G})$ のピークが存在することは, PAN T-300 繊維を構成している黒鉛微結晶子は均質なむので はなく，黒鉛綱平面のコヒーレント長さに分布があるとと 在している。G，D バンドの積分強度比 $\mathrm{R}=\mathrm{I}_{1350} / \mathrm{I}_{1560}$ およびそれらの $1 / 2$ 強度におけるピーク巾の半分 $\left(\mathrm{W}_{1 / 2}\right)$ と酸化率との関係をFig.9 亿示した。Gバンドの $W_{1 / 2}$ の值はポリフリルアルコールを $500^{\circ} \mathrm{C}$ で炭化して得たガ ラス状炭素の值 ${ }^{7)}$ とぼ等しい。 $\mathrm{R}$ の值は, ベンゼンの 気相熱分解によって得られた炭素繊維の值 ${ }^{8)}$ の約 3 倍で あった。 


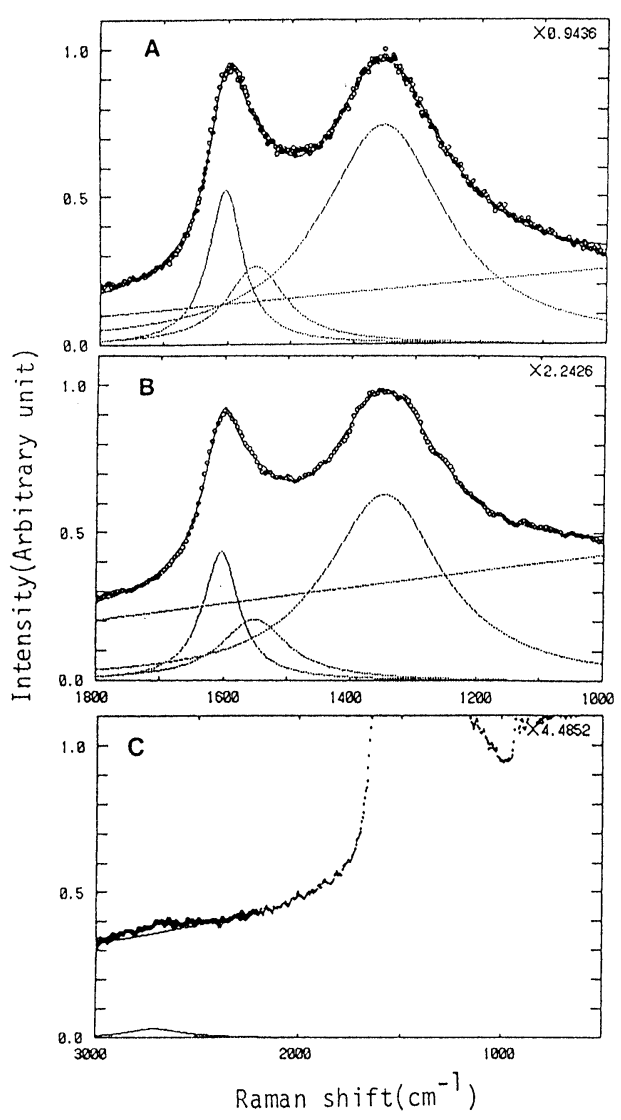

Fig. 8 Raman spectra of PAN T-300 carbon fibers oxidized at $525^{\circ} \mathrm{C}$.

A: 3\% burn-off. B, C: $59 \%$ burn-off.

レーザービームが炭素繊維中に侵入する深さは約 0.05 $\mu \mathrm{m}$ と推定されている ${ }^{19)}$ 。したがって, 炭素緎維表面に ごく近い領域の酸化に伴なう組成変化がラマンスペクト ルに反映されるととになる。一般に，乱れた構造をむつ 結晶子の方が黒鉛化の進んだ結晶子よりあ酸化され易い と考えられている9!。したがって, 炭素緎維内部に酸化 が進行するにつれて, より黒鉛化の進んだ結晶子の割合 がふえ，乙のため， Rは酸化率の増加とともに減少する と予想される。しかしながら， R, $\mathrm{W}_{1 / 2}$ の酸化化伴なう 変化量は, ベンゼン気相熱分解炭素繊維が熱処理を受け た時に示す変化量とくらべてずっと小さい。乙の結果は, PAN T- 300 瀻維を構成する微結晶子の平均的な黒鉛化 度が, 酸化の進行によってあまり変化しないととを示し ている。乙れは, 個々の微結晶子の化学反応性が均一で あることを前提とした自触媒型モデル(4)式の仮定を支持 する結果である。

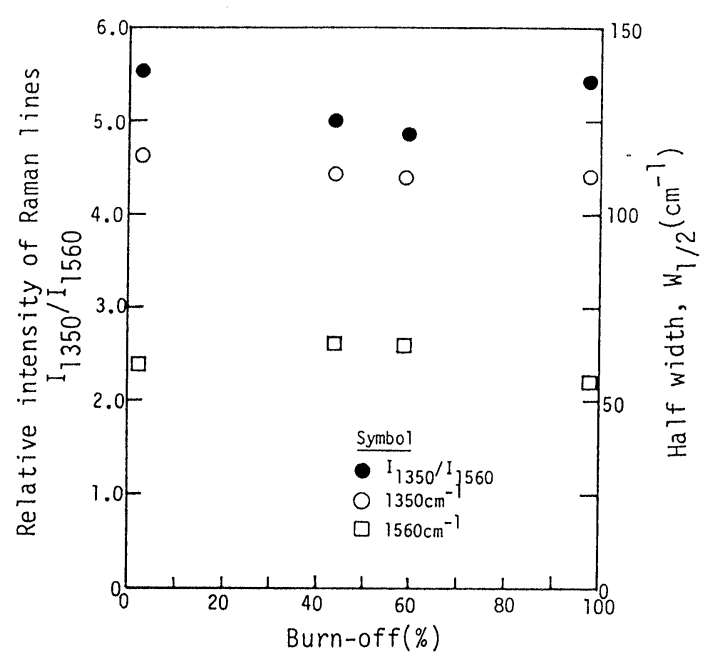

Fig. 9 Plot of the Raman intensity ratio $I_{1350} / I_{1560}$, and the halfwidth at half maximum linewidth for PAN T-300 carbon fibers oxidized at $525^{\circ} \mathrm{C}$.

\section{4. 考 察}

T-300 (A.R.) 繊維に対して当初考えられた肉減り反 応機構は, 動力学的解析, 繊維半径亡酸化率との関係打 よびSEMによる表面観察によって否定された。Jones と Thrower は, $2800^{\circ} \mathrm{C}$ で黒鉛化処理したPAN T- 300 繊維を50\%弱まで酸化し, SEM 観察を行った ${ }^{111}$ 。その 結果, PAN T-300繊維では黒鉛微結晶子の間に橋架け チェインが存在し, 微結晶子による八ニカム状のネット ワークが構成されているてとを示した。このネットワー クを構成している微結晶子は, そのエッジ面が䋐維表面 に露出している微結晶子よりも酸化されにくく, そのため, 黒鉛化処理を受けたPAN T-300繊維では八ニカム状 の腐食ピットが生ずる ${ }^{11)}$ 。一方, 本実験の T- 300 (A.R.) 繊維では, 酸化によって八二カム状の腐食ピットは生成 しなかった。その理由は, T-300 (A.R.) 緘維では個々 の微結晶子が小さいことと, その化学反応性には大差が ないためと考えられる。自触媒型の反応機構では, 炭素 繊維内部への酸素分子の侵入速度は律速要因とはならな い。空気酸化速度の違いから $\left.{ }^{3)}, 10\right), T-300$ (A.R.) 繊維 の微結晶子の酸化速度は黒鉛化処理を受けた T-300繊維 のそれよりあずっと大きいであろう。そのため, 酸化反 応の律速要因は微結晶子の酸化速度ではなく, それより あ酸化されにくい橋架けチェインや, ネットワークの酸 化による破壊速度にあると考えられる。ネットワークが 部分的に破壊されると, それに伴ってその部分に組み込 
まれていた微結晶子のエッヂ面が露出し，酸化が進行す る。このような反応機構は Branching reaction（分枝 反応 $)^{22)}$ のそれと似ており, 自触媒型の反応速度式を与 える。T-300 繊維（A.R.）は98\%の酸化を受けてあ粉末 にならず，繊維状の形状を保っていた。てのことは，微 結晶子を結ぶ橋架けネットワークが酸化さ机にくい屯の であることを示している。

反応速度が未反応部分の微結晶子の表面積に比例する と考えて，(5)式に扔けるパラメータを $\mathrm{n}=1, \mathrm{~m}=2 / 3$ と 扮いた動力学的解析屯試みた。しかし，乙のモデルは(6) 式よりあ実測值との一致が悪かった。未反応微結晶子の 活性化のメカニズムとしては, 前記の橋架けチェインの 破壊のほか, 反応熱による周囲の微結晶子の表面温度の 上昇や表面酸化物の生成などが考えられる。反応ガスの 接触表面積とは異なり, これらのメカニズムは微結晶子 の表面積にかならずしあ比例して作用しない。

$\mathrm{I}_{1350} / \mathrm{I}_{1560}$ の強度比 $\mathrm{R}$ はスペクトル分離の方法によっ て大きく変化する。Fig.8 亿示したローレンツ型分布に よる分離では, 各バンド強度の順列は $\mathrm{D}>\mathrm{D}^{\prime}>\mathrm{G}$ とな る。一方，同一のデータをガウス型分布を用いて分離を 行うと $\mathrm{D}>\mathrm{G}>\mathrm{D}^{\prime}$ の順列となり, $\mathrm{G}, \mathrm{D}^{\prime}$ バンドの強度 が逆転する。その結果，ガウス型分布による分離で得ら れる R 値はローレンツ型分布による值の $1 / 2$ となった。 さらに, $\mathrm{R}$ 值は微結晶子の黒鉛化度のほかにも, 粒径や 配向性にあ関係する ${ }^{19), 23) 。 し た か ゙ っ て ~} \mathrm{R}$ の絶対值から, 炭素繊維中の黒鉛成分と非晶質部分の比率の絶対值を議 論することは適当ではない。本報では，実測值との一致 が比較的良かったローレンツ型分布を用いたが，酸化率 に対する R の変化挙動はガウス型分布を用いた場合でも 同様であった。乱れた構造をむつ炭素に対してどの分布 曲線が適当であるかは6)，今後の検討課題である。

Fig.9を詳しく見ると, 定性的には次の傾向がある。G， $\mathrm{D}$ バンドに対する $\mathrm{W}_{1 / 2}$ 值は一定もしくは酸化によって ごくわずかに減少する。R值については，酸化の進行と と屯に減少し，高酸化率になると反転して増加する。乙 の傾向は，酸化のイニシェーションが非晶質部分である 耐酸化性の橋架けチェインの部分的な破壊であり，しか あ，その速度か酸化反応の律速段階となるという考え方 を支持する。

\section{5. 謝辞}

レーザーラマンスペクトルは, 当所燃料・材料工学部 材料設計研究室の井川直樹氏に測定していただいた。う マンスペクトルの分離には, 同研究室長崎正雅氏自作の プログラムを使用させていただいた。両氏のご好意に対 し，深く感謝いたします。

\section{文献}

1) 大谷杉郎，奥田謙介，松田 滋，“炭素繊維”近代 編集社, P453 (1983)

2) 安田栄一, 木村脩七, 炭素 1983 [No. 115] 196

3) 遠藤守信, 小山恒夫, 炭素 1982 [No. 101] 59

4) K.J. Bowles and G. Nowak, J. Composite Materials 22, 966 (1988)

5) I.M.K. Ismail, Carbon 25, 653 (1987)

6) R. Vidano and D.B. Fischbach, J. Am. Ceram. Soc. 61, 13 (1978)

7) M. Nakamizo, R. Kammereck and P.L. Walker, Jr., Carbon 12, 259 (1974)

8) T.C. Chieu, M.S. Dresselhaus and M. Endo, Phys. Rev. B26, 5867 (1982)

9) D.W. Mckee and V.J. Mimeault, "Chemistry and Physics of Carbon" Vol. 8, Marcel Dekker (1973) P. 151

10) K. Kowbel, E. Hippo and N. Murdie, 18th Biennial Conference on Carbon, Worcester, Massachusetts (1987), Proceedings and Program, P. 308

11) L.E. Jones and P.A. Thrower, ibid., P. 306

12) R. Bacon, Phil. Trans. Roy. Soc. Lond. A294, 437 (1979)

13) B. Harris, P.W.R. Beaumont and A. Rosen, J. Mater. Sci. 4, 432 (1969)

14) D.W. Mckee, Carbon 8, 623 (1970)

15) D.W. Mckee, ibid., 131 (1970)

16) J. Robertson, Adv. Phys. 35, 317 (1986)

17) J. Heremans, I. Rahim and M.S. Dresselhaus, Phys. Rev. B32, 6742 (1985)

18) R.J. Nemanich and S.A. Solin, Phys. Rev. B20, 392 (1979)

19) F. Tuinstra and J.L. Koenig, J. Chem. Phys. 53, 1126 (1970)

20) P. Lespade, R. Al-Jishi and M.S. Dresselhaus, Carbon 20, 427 (1982)

21) R. Al-Jishi and G. Dresselhaus, Phys. Rev. B26, 4514 (1982)

22) E.G. Prout, F.C. Tompkins, Trans. Faraday Soc. 40, 488 (1944)

23) G. Katagiri, H. Ishida and A. Ishitani, Carbon 26, 565 (1988) 